Whistleblowing as a new regulatory instrument in global governance the case of tax evasion

Porter , Tony ; Ronit, Karsten

Published in:

Cambridge Review of International Affairs

DOI:

10.1080/09557571.2018.1546278

Publication date:

2018

Document version

Early version, also known as pre-print

Citation for published version (APA):

Porter , T., \& Ronit, K. (2018). Whistleblowing as a new regulatory instrument in global governance: the case of tax evasion. Cambridge Review of International Affairs, 31(6), 537-560.

https://doi.org/10.1080/09557571.2018.1546278 


\section{Cambridge Review of International Affairs}

\section{Whistleblowing as a new regulatory instrument in global governance: the case of tax evasion}

\section{Tony Porter \& Karsten Ronit}

To cite this article: Tony Porter \& Karsten Ronit (2018) Whistleblowing as a new regulatory instrument in global governance: the case of tax evasion, Cambridge Review of International Affairs, 31:6, 537-560, DOI: 10.1080/09557571.2018.1546278

To link to this article: https://doi.org/10.1080/09557571.2018.1546278

册 Published online: 24 Jan 2019.

Submit your article to this journal $\asymp$

山 Article views: 220

Q View related articles $\sqsubset$

View Crossmark data \ulcorner

4 Citing articles: 1 View citing articles 


\title{
Whistleblowing as a new regulatory instrument in global governance: the case of tax evasion
}

\author{
Tony Porter \\ McMaster University
}

\author{
Karsten Ronit \\ University of Copenhagen
}

\begin{abstract}
The cross-border impacts of whistleblowing recently have become far more visible and consequential, as evident with the 'Paradise' and 'Panama Papers' leaks, which exposed tax and other financial wrongdoings of prominent personalities around the world, leading to scandals, resignations and prosecutions. Despite its new prominence, whistleblowing often continues to be seen as a series of ad hoc chance acts. We argue instead that whistleblowing is an increasingly institutionalized regulatory tool that is enabled by an emergent 'whistleblowing system', with similarities to other new forms of informal global governance. Whistleblowing can be controversial, and we develop a framework for assessing whether any particular whistleblowing event and the system that enables it are in the public interest. We then apply this analysis to the case of global tax evasion. We conclude that a whistleblowing system can make important contributions to difficult cross-border regulatory challenges such as tax evasion, especially where other governance systems fail.
\end{abstract}

\section{Introduction}

The leaks of the 'Paradise Papers' and the 'Panama Papers' have dramatically highlighted the global importance of whistleblowing in the governance of taxation. An article in Wired noted that the Panama Papers were 'the biggest leak in whistleblower history', estimated to be 2.6 terabytes, a thousand times larger than WikiLeaks' 20101.73 gigabytes, compared with the 1971 Pentagon Papers equivalent to less than 100 megabytes (Greenberg 2016). A co-founder of the Occupy movement referred to this as 'leaktivism's coming of age' (White 2016). The Paradise Papers are the second largest leak at 1.4 terabytes. ${ }^{1}$ These leaks were not only large but impactful, embarrassing world leaders and celebrities, and quickly leading to the resignation of ministers, reorganization of public administrations and pressures on banks involved in the scandals.

\footnotetext{
${ }^{1}$ <http://www.bbc.com/news/world-41880153>.
} 
This paper aims to contribute to a better theoretical understanding of the significance of whistleblowing in a global context. First, it will look at whistleblowing as an institutionalized global regulatory tool that works within an emerging 'whistleblowing system' and whose presence and properties have not yet been adequately analysed. Nascent whistleblowing systems exemplify important changes in the institutional characteristics of global governance that are hard to capture through existing theories. Second, a framework will be developed to address the questions about whether and when whistleblowing is in the public interest, provoked by the unconventional, unpredictable and often disruptive character of whistleblowing. Conceptual modifications to existing nationally focused approaches to whistleblowing that are called for when discussing whistleblowing and global governance will be highlighted.

The second part of the paper applies the outlined approach to whistleblowing systems as a regulatory instrument to global taxation, and discusses the potential of the unfolding whistleblowing systems to address particularly challenging global policy problems involving secrecy, such as tax evasion. Tackling the cross-border aspects of tax evasion has become a priority of policymakers in recent years, evident for instance in the Base Erosion and Profit Shifting project (BEPS) of the Organization for Economic Cooperation and Development (OECD), the United States (US) Foreign Account Tax Compliance Act (FATCA) and the European Union's EU's Directive on Administrative Cooperation in the Field of Taxation. However, detecting tax evasion remains challenging. The ensuing discussion thus analyses how whistleblowing has evolved to combat cross-border tax evasion and for what types of global policy problems this new regulatory instrument may be most suited. In spite of the increased visibility of the role played by whistleblowing, especially with the Panama and Paradise Papers, and of its impact in contributing to punishment for wrongdoing, the potentials and limitations of whistleblowing as a regulatory instrument for addressing taxation issues have not yet been adequately considered in a global context. Therefore, an important contribution of the paper is to highlight the building of new institutions operating across jurisdictional boundaries with the explicit goal to set new agendas, to influence policy and to trigger punishments, at the domestic and international level. In this process, the institutions should not be studied in isolation but in their combined effort. Based on different and sometimes overlapping incentives, they are concerned with carving out specific roles that define their activities in relation to other public and private organizations.

The following section briefly identifies the insights provided by the existing literatures on global governance, regulation and whistleblowing, before embarking upon the theoretical analysis of the emerging whistleblowing systems. The empirical analysis of whistleblowing with regard to taxation more specifically is developed in the second half of the paper. It will be concluded that whistleblowing in relation to global tax evasion is mainly managed by private actors beyond the control of states and that whistleblowing offers certain promises for regulating challenging activities such as tax evasion. 


\section{The literatures on global governance, regulation and whistleblowing}

This section reviews the literatures relevant to the growth of whistleblowing at the international level. It focuses first on the general character of the diffusion of practices in contemporary global governance studies before turning to the literature on regulation that helps characterize whistleblowing as a regulatory tool. The section concludes with the specific literature on whistleblowing.

\section{Insights from the literatures on global governance}

In recent decades, there have been widely recognized changes in global governance that provide the context to whistleblowing. Two types of changes are particularly relevant here: the multiple forms of institutions that interact in global governance and the multiple types of processes that are sources of global rules.

First, a key feature in the debate on global governance is the emergence of multiple forms of governance through state, market and civil society. Rather than creating centralized bureaucratic capacity in formal intergovernmental organizations, these new forms of governance mobilize diverse sets of actors and institutions from across the world. This development has included the emergence of private bodies that have the potential to govern as a complement or alternative to traditional public policy, such as third-party certifications and codes of conduct, critical civil society groups such as Transparency International (TI) and business associations such as the International Chamber of Commerce (ICC), two organizations that have issued various whistleblowing guidelines. ${ }^{2}$

While some sceptics argue that increased reliance on private mechanisms by definition moves policy away from the public interest, this paper argues that different procedures of participation, accountability and transparency can enhance the publicness of private arrangements (Porter and Ronit 2010). Decades ago it was recognized that governmental institutions can be captured by private interests (Stigler 1971), and today certain private institutions, such as media companies, can serve public functions, including in a global context. It no longer makes sense to assume that governmental organizations are always better at promoting the public interest than private organizations. Criteria for assessing the degree of alignment of private standards with the public interest are emerging, ${ }^{3}$ and can be used to assess the relationship between whistleblowing and public interest. ${ }^{4}$

The second change in global governance is evident in the variety of processes that produce global rules. Some rules and norms are adopted at international levels and managed by international bodies. Treaties, for instance,

${ }^{2}$ For the ICC, see <http://www.iccwbo.org/advocacy-codes-and-rules/areas-of-work/ corporate-responsibility-and-anti-corruption/whistleblowing/ $>$. The role of TI is discussed further below.

${ }^{3}$ See for instance the ISEAL Alliance Codes of Good Practice (<http://www.isealalliance. org/our-work/defining-credibility/codes-of-good-practice $>$ ) and the International Organization for Standardization (ISO) 26000 standards on social responsibility (<http://www.iso.org/iso/ home/standards/iso26000.htm $>$ ), both of which are standards for private standards and practices.

${ }^{4}$ On publicness, see Best and Gheciu (2011). 
remain important, as in the case of whistleblowing with the OECD's AntiBribery Convention, ${ }^{5}$ and the United Nations' (UN's) own whistleblowing protections, adopted to govern its internal operations. ${ }^{6}$ There are also other ways of making rules. Some rules may primarily be based in one or two countries but nevertheless contribute to global governance because of their cross-border influence and connections. National laws can also have extra-territorial effects, for instance, when compliance with a particular jurisdiction's laws by a multinational corporation requires adjustments in its operations outside that jurisdiction. Cross-border policy emulation, which can be encouraged by the above mechanisms but also occurs without them, can contribute to the diffusion of new governance practices as well. Scholars have begun to identify the conditions under which such diffusion is likely (Simmons and Elkin 2004). In global governance, the importance of the most powerful states in the globalization of policies is well recognized. In particular, since World War II the US has projected its own practices beyond its borders, through governmental action or through the practices of private actors such as business and civil society actors (Simmons 2001; Levi-Faur 2005). In a comparative perspective, the development of whistleblowing has been most advanced in the US, and US practices have been held up as examples for other countries to emulate.

In sum, these governance changes over the last several decades provide the wider context for the development and global dissemination of whistleblowing as a new governance practice. While there is no world government, there are multiple actors through which governance can be globalized when public and private actors combine their efforts or when private actors take independent action. Furthermore, such practices may be adopted at the global level or adopted in one place and transferred to other parts of the world.

\section{Insights from the literatures on regulation}

Closely related to the changes in global governance are changes in global regulation. As will be discussed in subsequent sections, these changes are important for the emergence of whistleblowing as a global regulatory instrument. However, it is first necessary to understand how the different functions and organizations can be connected vertically and horizontally to create effective regulatory arrangements that do not necessarily need to be contained within a single regulatory body. This connection is especially useful at the global level, since the creation of integrated stand-alone regulatory bodies is typically resisted by sovereign states.

An important feature in the literature on regulation is the vertical relationship between different types of rules, driven in part by the challenge of

\footnotetext{
5 The full name is the OECD Convention on Combating Bribery of Foreign Public Officials in International Business Transactions. The text is at <http://www.oecd.org/daf/anti-bribery/ ConvCombatBribery_ENG.pdf $>$. The Convention calls for 'companies to provide channels for communication by, and protection of, persons not willing to violate professional standards or ethics under instructions or pressure from hierarchical superiors, as well as for persons willing to report breaches of the law or professional standards or ethics occurring within the company in good faith and on reasonable grounds, and should encourage companies to take appropriate action based on such reporting'. Section XCv, 24-25.

6 <http://www.un.org/apps/news/story.asp?NewsID=16993\#.WCdb_krLmY>. The current policy can be found at <http://www.un.org/en/ethics/protections.html $>$.
} 
managing increasingly complex and technical problems. Three types of vertical relationships are relevant: a coercion/voluntary relation, a public oversight/ private implementation relation and a global standard/national implementation relation, the first element in each of these three distinctions being associated with a larger scale or degree of authority. First, the relationship between public and private regulation may take the form of a regulatory pyramid, where most routine matters are handled privately and voluntarily by business, but a number of more serious matters are escalated, and public regulators can be brought in with coercive sanctions (Ayres and Braithwaite 1992). Midway down this regulatory hierarchy, private actors create forms of self-regulation to govern their own behaviour or to invite other private actors to join. ${ }^{7}$ Second, private regulation may be usefully sensitive to the experiences and challenges of the regulated business actors, and in a less costly and burdensome manner than public regulation. However, private regulation may also provide opportunities for private actors to abuse their unique familiarity with a given issue area and manipulate the regulations or escape their obligation to comply. This problem can be mitigated through formal or informal oversight by public authorities, through the use of courts, regulatory supervision, legislative review or the threat of stronger public regulation. Third, broad standards may be set at the global level and then be implemented nationally with specific public or private rules consistent with these broad global standards.

Horizontally, the creation of regulatory arrangements encompasses different stages, which unfold over time. Typically, these include agenda-setting, formulation, decision, implementation and evaluation stages which would be organized around a state and its policy processes. The regulatory implementation stage, which is often the most challenging, can further be subdivided into the following sequences: monitoring, compliance, adjudication and sanctioning (Porter and Ronit 2015). It is useful to recognize these stages and sequences because they identify linked functions that must be carried out for a policy or regulatory process to be established. However, in today's more complex and globalized settings, as with the vertical relationships discussed above, these functions and stages can increasingly be provided by different organizations, some or all of which can be private (Porter and Ronit 2006; Abbott and Snidal 2009). For instance, standards may be formulated by one organization, compliance may be monitored by another and sanctioning may involve a mix of market pressures and threats from public authorities. At the global level, these types of sanctioning can be more complex than conventional punishments at the national level, and include, for instance, cross-border damage to a wrongdoer's reputation or brand. However, these types of sanctioning can also activate more conventional national penalties that would not have occurred without the global institutions.

With regard to whistleblowing institutions it appears that both vertical and horizontal interactions linking different actors in problem solving are involved. Their regulatory significance would be easy to overlook if it were not recognized that effective regulation does not require all the regulatory functions to be contained within unified public organizations, but instead can be provided

\footnotetext{
${ }^{7}$ Examples include the standards of the ISEAL Alliance, or the ISO 26000 standards for social responsibility.
} 
by different public and private actors and institutions interacting along the aforementioned vertical and horizontal dimensions.

\section{Insights from the literatures on whistleblowing}

The complexity of global governance and regulatory arrangements having been addressed, this section now turns to the literature on whistleblowing to identify the degree to which whistleblowing is becoming a recognizable and institutionalized part of these complex arrangements.

The academic whistleblowing literature includes the fields of management (how firms can manage whistleblowing policies or episodes); law (judicial decisions or the design of legal protections); public administration (personal motives and institutional conditions for whistleblowing); regulatory studies (the levels and methods of monitoring and reporting); and political science (appeals to politicians from employees) (Near and Miceli 2016; Walker 2015; Cho and Song 2015; Etienne 2015; Ting 2008). Additionally, many reports and policy or legal documents are produced by governmental, business and civil society actors.

An important debate in the literature centres around the questions of how to define whistleblowing and how to differentiate it from other types of information disclosure, such as destructive hacking. A widely cited definition has been provided by Near and Miceli (1985): 'the disclosure by organisation members (former or current) of illegal, immoral or illegitimate practices under the control of their employees, to persons or organisations that may be able to affect action'. This limits the understanding of whistleblowing in three ways: the whistleblower must be a member of a defined organization; the targeted practices must be under that organization's control; and the information must be directed to competent authorities. A key motivation for such restrictions is to identify activities for which legal protections are most likely to attract support, and this approach has indeed been impressively successful in overcoming earlier perceptions of the illegitimacy or immorality of whistleblowing and putting legal protections in place in an increasing number of jurisdictions.

While acknowledging and valuing the merits of such a definition, it appears that a more expansive definition is needed when analysing whistleblowing at the global level. The whistleblowing literature has already begun to note the increasingly porous and complex character of contemporary firms (Andrade 2015; Vandekerckhove 2006), which is majorly amplified at the global level. Global supply chains, which account for an increasing share of crossborder economic transactions, can involve many different tiers of suppliers of different sizes linked through contracts and logistical arrangements that are altered from year to year. A similarly networked character can be observed in the global 'tax industry' and cases of tax evasion, as evident in the 'global wealth chains' linking wealthy individuals and firms with offshore centres identified by Seabrooke and Wigan (2017). These types of porous complex organizations can be especially important targets for whistleblowing as a regulatory mechanism, since conventional authorities are likely to have more difficulty detecting their potentially illegal activities than with those of welldefined national firms. Moreover, at the global level there are likely no competent authorities comparable to those at the domestic level, and eliciting actions 
from multiple or foreign national authorities may be too complex for whistleblowers.

Given this complexity and organizational porosity this paper proposes to replace the definitional restrictions discussed above with other criteria for differentiating between legitimate and illegitimate disclosures of information at the global level. Although this may complicate the effort to strengthen legal protections for whistleblowing in the short term, it is likely to greatly increase the volume of cross-border wrongdoing that whistleblowers contribute to deterring and sanctioning. Moreover, as shown in the case study of tax evasion below, public authorities have been making effective use of information disclosures that do not fit the conventional definition of whistleblowing but have key properties that merit the whistleblowing label.

The proposed definition includes types of public-interested leaks and information disclosures that may be initiated from outside the relevant firm, that may target its clients, suppliers or stakeholders and that may be directed to global media and other actors rather than competent legal authorities, with sanctions working through reputational damage rather than legal penalties. The definition is restricted by requiring the presence of a 'legitimizing framework', discussed more fully below, to distinguish between disclosures that are in the public interest and ones, such as destructive hacking, that are not. This is similar to, but goes beyond, criteria such as 'good faith and on reasonable grounds' which the G20 references in its best practices for whistleblowing. ${ }^{8}$ Therefore this paper defines whistleblowing as 'a disclosure of confidential information with the goal of contributing to exposing, deterring or punishing activities that are widely perceived as illegitimate or illegal'.

An important vehicle for the international dissemination of whistleblowing as a regulatory instrument is its links to anti-corruption campaigns. International legal instruments that address whistleblower protections include the UN Convention against Corruption, the 2009 OECD Recommendation of the Council for Further Combating Bribery of Foreign Public Officials in International Business Transactions (Anti-Bribery Recommendation), the 1998 OECD Recommendation on Improving Ethical Conduct in Public Service, the Council of Europe Civil and Criminal Law Conventions on Corruption, the Inter-American Convention against Corruption and the African Union Convention on Preventing and Combating Corruption. As the G20 report on this list notes, 'such provisions have strengthened the international legal framework for countries to establish effective whistleblower protection laws'. 9

There are numerous ways that private actors and new technologies have assisted in the globalization of whistleblowing as well. Whistleblowing NGOs and networks, such as the Government Accountability Project, TI and the International Whistleblowing Research Network, have promoted the emergence of whistleblowing systems.

${ }^{8}$ OECD, 'G20 Anti-Corruption Action Plan: Protection of Whistleblowers.' Study on Whistleblower Protection Frameworks, Compendium of Best Practices and Guiding Principles for Legislation. OECD, 2011. https://www.oecd.org/g20/topics/anti-corruption/48972967.pdf

9 OECD. 'G20 Anti-Corruption Action Plan: Protection of Whistleblowers.' Study on Whistleblower Protection Frameworks, Compendium of Best Practices and Guiding Principles for Legislation. OECD 2011, 5. 
Taken together, this literature highlights how the elements of global governance and regulation identified in the previous sections are also evident in the growing presence of whistleblowing-related developments globally. Whistleblowing rules have involved traditional treaties, more informal best practices developed by the G20, a public body, and non-governmental actors that operate globally or regionally.

Despite the valuable insights that the existing literatures have provided into the concrete mechanisms of whistleblowing, their global dissemination and how to assess their publicness, more work is needed to analyse the existing and potential contribution of whistleblowing to global governance and regulation.

\section{Conceptualizing whistleblowing as a global regulatory instrument}

This section draws out how emerging whistleblowing systems use a mix of public and private authority and the mechanisms that are invoked, including the issue of how to know when whistleblowing is in the public interest. The notion of 'system' is used loosely here to refer to an emergent set of recognizable links between actors and institutions, in contrast to the more tightly integrated and operationally closed arrangements that are the focus of some systems theories. ${ }^{10}$

\section{The organization of whistleblowing}

The actors and their various properties and linkages can be considered a system in emergence. Figure 1 illustrates a typical whistleblowing system and identifies specific tasks managed by the actors in the area of tax evasion. The foursided shape at the centre represents the 'target' organization from which the information disclosed by the whistleblower originates.

As noted above, the whistleblower may be an employee of the organization or a related entity, but the organization's information may also be disclosed by an external hack. Many organizations have internal processes for managing complaints, which may encourage potential whistleblowers to seek resolution of their concerns within the target organization itself. Arrayed around the target organization are the various bodies that interact in the system of whistleblowing. This view is consistent with the new forms of governance discussed in the previous section, which can involve a variety of changing actors and rules. For instance, civil society organizations and business associations may promote or oppose whistleblowing. Media and journalists may publicize the information disclosed by the whistleblower and put pressure on the target organization. Public rule-makers may create rules protecting whistleblowers or rules that criminalize the conduct of the target organization that troubled the whistleblower. Courts and law enforcement may act on violations of the law which the whistleblower reveals. The organizations helping whistleblowers can include ones, such as WikiLeaks or the International Consortium of Investigative Journalists, that help disseminate the disclosed information, or

10 These arrangements could also more precisely be described as 'assemblages' or 'ecologies', but for our purposes here the more widely used 'system' label is sufficient. 


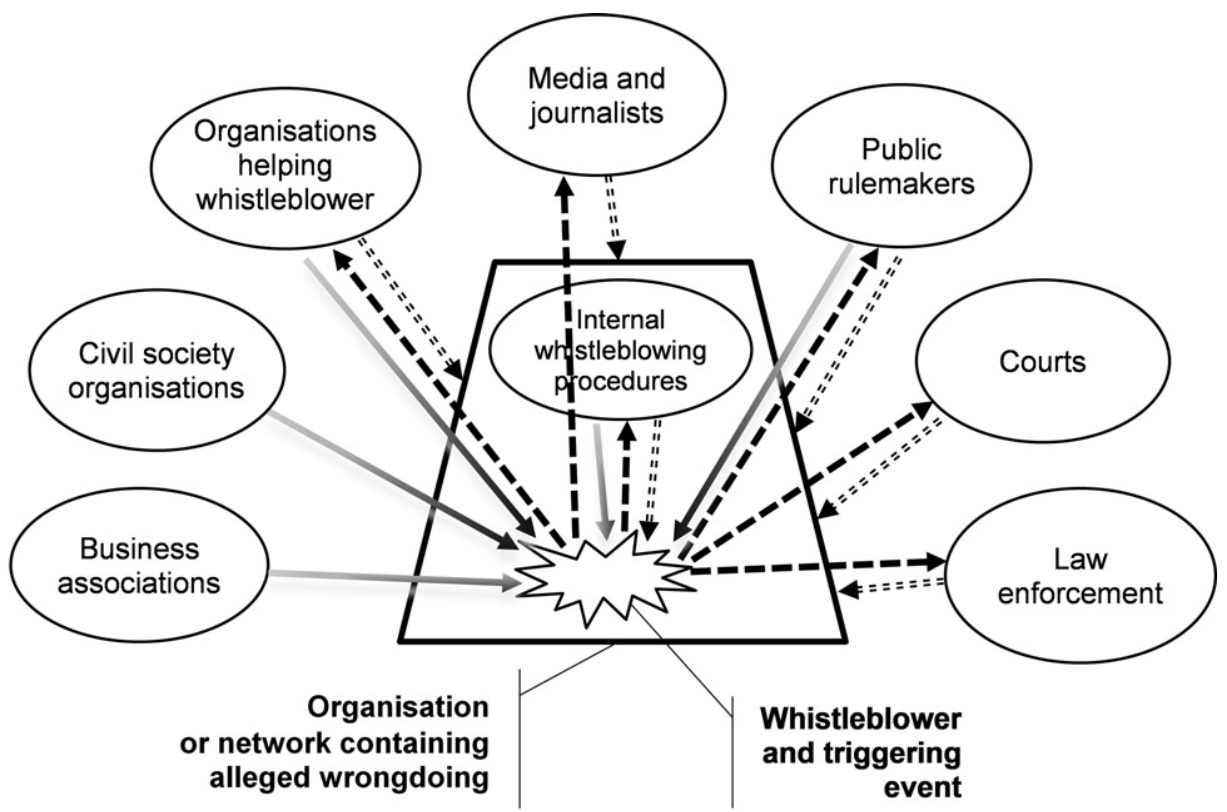

\begin{tabular}{|c|l|}
\hline Legend & $\begin{array}{l}\text { The time and location when the whistleblower, the whistleblower's } \\
\text { motivation, and access to the information that will be disclosed come } \\
\text { together. }\end{array}$ \\
\hline$\square$ & $\begin{array}{l}\text { The organization or network from which the information is disclosed. Often } \\
\text { organizations have internal procedures encouraging whistleblowers to } \\
\text { resolve issues internally. Today many enterprises involve more } \\
\text { decentralized networks. }\end{array}$ \\
\hline$-=\begin{array}{l}\text { Information flow from whistleblower once the whistle is blown. These flows } \\
\text { may lead to legal or reputational sanctions. }\end{array}$ \\
\hline$\longrightarrow \begin{array}{l}\text { Legal or reputational remedy or rejection in response to whistle being blown. } \\
\text { For instance, legal responses may come from law enforcement, and } \\
\text { reputational responses from the media's framing of the whistleblowing. }\end{array}$ \\
\hline $\begin{array}{l}\text { Advocacy and implementation of protections for whistleblowers. These can } \\
\text { be general for all whistleblowers, or specific to one case, and may occur } \\
\text { before and after a whistle is blown. Protections encourage whistleblowing. }\end{array}$ \\
\hline
\end{tabular}

Figure 1. A whistleblowing system.

ones that support whistleblowing, such as the Government Accountability Project.

The different organizations displayed in Figure 1 and the individuals associated with them have varying convergent and competing incentives to engage in the process of whistleblowing. A desire to contribute to the public interest and to act ethically should not be underestimated: often whistleblowing takes great personal courage given the risks. NGOs such as TI may support whistleblowers because the latter's disclosures help advance the NGOs' larger mission. News media benefit commercially from the types of stories that whistleblowers reveal, tempered by professional standards that govern journalists and safeguard their credibility. Public authorities may use information disclosed by whistleblowers which would have been difficult to obtain otherwise. 
The emerging system lacks clear coordination mechanisms, and different ambitions and interest may conflict. Whistleblowers may have quite personal motives that stimulate certain actions and may not necessarily bring full and unbiased information through leaks. NGOs have different motives to engage in tax issues and while some direct attention to development and failed-state conditions others concentrate on the continuing funding of welfare states. News media are involved in strong competition at domestic and international levels and primarily launch campaigns in areas that are of interest to their readership but may avoid issues that are technically highly complicated but helpful to other actors in the system. Relying on and purchasing information from a host of unknown sources, states may act spontaneously and not build up the needed capacity to boost the role of governments in combating tax evasion and even hinder intergovernmental initiatives.

In spite of the different agendas pursued by these various actors and institutions, the sum of the latter's often disparate efforts can contribute to the progressive strengthening of the systemic properties of whistleblowing even in the absence of overall coordination. The functions discussed in the previous section ${ }^{11}$ enable both the emergence and ongoing operation of whistleblowing. For instance, a civil society organization such as TI may engage in agenda-setting to try to strengthen protections for whistleblowers, which will further institutionalize whistleblowing. Similarly, public rule-makers, such as legislators or regulators, may create incentives or protections for whistleblowers, which may both strengthen the overall principles and mechanisms of whistleblowing and encourage and manage particular acts of whistleblowing. Consistent with the literatures on global governance, a mix of public and private organizations also involves a mix of global and national ones.

The vertical aspect of regulatory arrangements is evident in the steps that any particular act of whistleblowing involves. These measures can include a variety of public and private elements. The great majority of whistleblowers start by raising their concerns within the organization that employs them. If the whistleblower's employer fails to address the whistleblower's concerns there is the possibility that he or she will go outside the organization, to the media or government (Near and Miceli 2016). Ethically driven hackers may also begin by disclosing information publicly. Whistleblowing then follows a 'tiered approach' that is somewhat similar to 'responsive regulation' in regulation theory, where more severe compliance mechanisms are only activated after more voluntary ones fail (Andrade 2015; Ayres and Braithwaite 1992).

\section{Whistleblowing in complex global settings: norms and legitimacy}

As noted above, it is important to expand the definition of whistleblowing in a global context, where organizations are often more complex and porous and competent authorities are not always easily identified or accessed by whistleblowers. The types of actors that can be considered whistleblowers need to be broadened to include ethical hackers and leakers, although their relations with the concrete organizations are qualitatively different from traditional

${ }^{11}$ Similar types of bringing together of functions in the sequences involved in the implementation of self-regulation have been identified by Porter and Ronit (2015). 
whistleblowers'. Similarly, because there may not be an easily identified or accessed competent authority, various intended recipients of the disclosed information need to be taken into account. At the global level, the pathways between a disclosure of information and its ultimate positive effects with regard to deterring or punishing wrongdoing may be complex and varied. For instance, media reports may generate public outrage, consequently leading a national authority to take action, which then contributes to a change in global norms or an increase in reputational risk, eventually inspiring a multinational firm to crack down on its employees' wrongdoing.

Simultaneously, it is very important to be able to distinguish legitimate information disclosures from ones that are destructive or predominantly motivated by private gain or adventure, in order not only to prevent harmful information disclosures, but also to retain the legitimacy that whistleblowing has obtained by restricting the range of activities to which this label is applied. Mixed motives may be involved. The information disclosure may be motivated by private interests, such as getting undeserved revenge on an employer, getting a qui tam payment (based on a share of the recovered assets or monies), gaining fame or assisting the employer's competitor or opponent (Broderick 2007). On the one hand, the ability to discuss certain issues inside an organization, without the fear that they will be circulated publicly can be in the public interest, since confidentiality can facilitate decision-making and is vital to the trust that sustains social collectivities. On the other hand, governments and firms can seek to conceal information in ways that are contrary to the public interest, including fraud and other legal violations, and in such cases whistleblowing is an appropriate and valuable remedy.

Therefore, we need criteria other than whether a governance instrument or action is governmental or non-governmental to assess whether it is in the public interest or not (Best and Gheciu 2011). Governmental processes can often be captured by private interests, and private actors and institutions can produce public goods. The publicness of a process or an act then depends on the presence or absence of certain properties associated with it, rather than whether it is initiated by governmental or non-governmental actors, and participation, accountability and transparency can serve as useful starting points. ${ }^{12}$

\section{Discerning the public interest in whistleblowing: a legitimizing framework}

It is particularly important to focus on the framework within which legitimate whistleblowing acts take place. This allows varied types of actors with varied types of interests to be included, shifting the criterion for the legitimacy of the information disclosure from the types of actor, motivation and target, to an evaluation of the institutional process and its alignment with global norms. This paper refers to this institutional process as the 'legitimizing framework'. This framework could include the involvement of public authorities in the assessment of the whistleblower's information, which can lend legitimacy to the process if the public authorities are independent of the organization on

12 These three criteria are widely used, sometimes with different labels. These criteria were applied by Porter and Ronit (2010). The criteria highlight a process approach to the public interest, rather than an outcomes approach. For a similar approach see Mattli and Woods (2009). 
Table 1. Major whistleblowing leaks in tax evasion

\begin{tabular}{|c|c|c|c|}
\hline Year & Leak & Nature of leak & Impact \\
\hline 2008 & Kieber & $\begin{array}{l}\text { - Account information from } \\
5800 \text { clients of Liechtenstein } \\
\text { Bank, collecting } € 4 \text { million } \\
\text { from German authorities. }\end{array}$ & $\begin{array}{l}\text { - Client tax evasion altered } \\
\text { Liechtenstein Bank } \\
\text { secrecy rules. }\end{array}$ \\
\hline 2008 & Elmer & $\begin{array}{l}\text { - Offshore bank account of } \\
2000 \text { 'high net worth } \\
\text { individuals' and } \\
\text { corporations. } \\
\text { - Julius Baer's role in alleged } \\
\text { tax evasion in } \\
\text { the Cayman Islands. }\end{array}$ & $\begin{array}{l}\text { No action from Swiss } \\
\text { courts. } \\
\text { - Elmer tried for violating } \\
\text { Swiss banking secrecy law. }\end{array}$ \\
\hline 2009 & Birkenfield & $\begin{array}{l}\text { - Recovery of US } \$ 780 \text { million } \\
\text { and names. } \\
\text { - US } \$ 5.5 \text { billion collected } \\
\text { from IRS Offshore } \\
\text { Voluntary Disclosure } \\
\text { Program from fear of } \\
\text { the leak. }\end{array}$ & $\begin{array}{l}\text { - Closure of Swiss banking } \\
\text { programmes. } \\
\text { - Winding down of Swiss } \\
\text { bank secrecy. }\end{array}$ \\
\hline 2013 & $\begin{array}{c}\text { Offshore } \\
\text { Leaks }\end{array}$ & $\begin{array}{l}\text { Data from cache of } 2.5 \\
\text { million leaked offshore files } \\
\text { obtained by ICIJ. } \\
\text { Records detail } 30,000 \\
\text { offshore holdings of people } \\
\text { and companies in more } \\
\text { than } 170 \text { countries and } \\
\text { territories. }\end{array}$ & $\begin{array}{l}\text { - Amplified political will of } \\
\text { EU Commission to tackle } \\
\text { tax evasion. } \\
\text { - Searchable database created } \\
\text { by ICIJ. } \\
\text { - High-profile resignations. }\end{array}$ \\
\hline 2014 & $\begin{array}{l}\text { Luxembourg } \\
\text { Leaks }\end{array}$ & $\begin{array}{l}\text { Secret deals between global } \\
\text { corporations and } \\
\text { Luxembourg tax authorities } \\
\text { exempting corporations } \\
\text { from paying tax in other } \\
\text { EU countries. }\end{array}$ & $\begin{array}{l}\text { Embarrassment to local } \\
\text { government and } \\
\text { corporations. } \\
\text { - Crisis for Luxembourg and } \\
\text { European cooperation. } \\
\text { - Real threat of prosecution } \\
\text { to whistleblowers. }\end{array}$ \\
\hline 2015 & $\begin{array}{l}\text { Swiss } \\
\text { Leaks }\end{array}$ & $\begin{array}{l}\text { - Identified private accounts } \\
\text { with Swiss branch of HBSC. } \\
\text { - Revealed how arrangements } \\
\text { were made to avoid } \\
\text { paying tax. }\end{array}$ & $\begin{array}{l}\text { - Huge pressure on bank and } \\
\text { Swiss authorities. } \\
\text { - Shows tax evasion involves } \\
\text { several parties. }\end{array}$ \\
\hline 2015 & $\begin{array}{r}\text { Football } \\
\text { Leaks }\end{array}$ & $\begin{array}{l}\text { - Players, agents, } \\
\text { intermediaries and clubs } \\
\text { involved in financial } \\
\text { transactions to avoid or } \\
\text { reduce paying tax. } \\
\text { - Manipulation or violation of } \\
\text { tax laws and rules of } \\
\text { Fédération Internationale de } \\
\text { Football Association (FIFA). }\end{array}$ & $\begin{array}{l}\text { - Traditional public } \\
\text { regulation is inadequate to } \\
\text { regulate and monitor the } \\
\text { industry. } \\
\text { - Reputation damage to } \\
\text { players, clubs, etc. } \\
\text { - EIC created to disseminate } \\
\text { information and } \\
\text { protect sources. }\end{array}$ \\
\hline 2016 & $\begin{array}{l}\text { Panama } \\
\text { Papers }\end{array}$ & $\begin{array}{l}\text { Wealthy individuals in } \\
\text { business and government } \\
\text { try to evade paying tax. } \\
\text { ICIJ plays especially } \\
\text { prominent role/ }\end{array}$ & $\begin{array}{l}\text { Weaknesses in monitoring } \\
\text { and sanctioning of tax } \\
\text { evasion, and enabling role } \\
\text { of law firms. }\end{array}$ \\
\hline
\end{tabular}




\begin{tabular}{|c|c|c|c|}
\hline Year & Leak & Nature of leak & Impact \\
\hline 2017 & $\begin{array}{c}\text { Paradise } \\
\text { Papers }\end{array}$ & $\begin{array}{l}\text { Seven million records from } \\
\text { offshore law firm Appleby, } \\
\text { from } 1950 \text { to 2016, } \\
\text { connected to people in } 180 \\
\text { countries. } \\
\text { - Instances of tax evasion } \\
\text { embarrassing to } \\
\text { global elites. }\end{array}$ & $\begin{array}{l}\text { - New data incorporated into } \\
\text { searchable database. } \\
\text { Investigations, arrest } \\
\text { warrants and strengthening } \\
\text { of tax compliance. }\end{array}$ \\
\hline 2018 & $\begin{array}{c}\text { West Africa } \\
\text { Leaks }\end{array}$ & $\begin{array}{l}\text { Collaboration between ICIJ, } \\
\text { West African Norbert } \\
\text { Zongo Cell for Investigative } \\
\text { Journalism (Cenozo) and } \\
\text { reporters from } 11 \text { countries, } \\
\text { drawing on existing } \\
\text { ICIJ data. }\end{array}$ & $\begin{array}{l}\text { Exposed secret accounts } \\
\text { and tax evasion of powerfu } \\
\text { political and corporate } \\
\text { actors in West Africa. }\end{array}$ \\
\hline
\end{tabular}

which the whistle has been blown. Alternatively, the legitimizing framework could involve norms or standards that specify how to assess the integrity and fairness of the whistleblowing act and its effects. As noted in the previous section, these types of rules about private governance initiatives have developed in other areas of global governance. ${ }^{13}$ These frameworks assist with accountability. Elements of a legitimizing framework can include: whether it is governed or shaped in some manner by widely agreed norms and standards even if there is not universal consensus on them; whether there is a stated public interest in the disclosure or a hack is motivated by the hacker's desire for notoriety; and whether the different bodies organizing whistleblowing have the capacity to assess whether the whistleblower met the 'good faith' standard that is becoming a common requirement in whistleblowing.

As will become evident in final section of this paper, the International Consortium of Investigative Journalists (ICIJ) and their handling of the Panama and Paradise Papers matched the criteria for public interest whistleblowing much better than key disclosures on Wikileaks. The ICIJ is a private organization, but it is governed by journalistic and ethical standards in a way that WikiLeaks is not. Additionally, public authorities have increasingly displayed a willingness to make use of information that has been disclosed by informants, leakers or hackers that previously would have fallen outside more restrictive definitions of whistleblowing. The disclosed information has been integrated into more conventional legal, policy, regulatory or enforcement processes, thereby confirming the information's legitimacy.

In the future, it will be important to continue to strengthen and make more explicit the public-interest norms that separate ethical and beneficial whistleblowing from destructive information disclosures. As in global governance more generally, this norm-creation process will likely involve an interacting mix of initiatives from national governments, possibly acting extraterritorially; NGOs like TI; global public institutions such as the G20 and OECD,

13 Thomas Franck has pointed to such 'second order' rules as important in the legitimacy of international law (Franck 1990). 
professional associations, and business actors such as the ICC. Such evolving norms should not undermine the legitimacy that whistleblowing has already achieved by restricting the range of actors to which the 'whistleblowing' label has been applied. More restrictive criteria can still be drawn upon in assessing the public-interestedness of any particular disclosure in more conventional cases of whistleblowing. However, the development of a 'legitimizing framework' could extend the benefits of whistleblowing to the more dynamic yet less conventional global settings.

\section{Experiences with whistleblowing: the case of global tax evasion}

At the global level, the emergence of a whistleblowing system for tax evasion appears to display the characteristics set out in the first section of this paper. These characteristics include the interaction of multiple types of actors reflecting different regulatory functions. Whistleblowing in taxation is underdeveloped compared with the closely related areas of corruption and financial fraud. These differences are evident in the US, where whistleblowing has been most institutionalized and has inspired global initiatives. Nevertheless, the increasing number and scale of tax-related cases, as well as the institutionalization of the global mechanisms for managing these, indicate the gradual establishment of a whistleblowing system for tax evasion. The emergence of a 'legitimizing framework' is also demonstrated by the role played by the ICIJ, which, in contrast to Wikileaks, has developed clear ethical guidelines that help identify the public interest in information provided by whistleblowers and leakers. Public authorities have further legitimized unconventional information disclosures, which might previously not have fitted conceptions of whistleblowing, by soliciting, using or responding to this information. Globally, a key development was the 2008 payment by German authorities of $€ 4.2$ million to Heinrich Kieber, a former employee of a Liechtenstein bank, for stolen bank data on approximately 600 tax evaders. More recently, Danish tax authorities negotiated and bought information from the Panama Papers through an unknown source to hunt down Danish tax evaders (Harding 2016). Additional examples of the increasing use by tax authorities of information from whistleblowing or leaks are provided below.

Table 1 lists the ten main whistleblowing cases relevant to global taxation. While space considerations preclude discussing these in detail, it is important to note the number of consequential cases and the significant effects they have had. The cases are listed in chronological order by the year of the disclosure of the information. While a full discussion of each case goes beyond the scope of this article, we do analyse the ways in which each of the first three cases signals the emergence of a whistleblowing system for global tax issues, and briefly address the significance of the remaining seven cases.

The first case was significant because of the payment Heinrich Kieber received from the German authorities. There were various effects as authorities in other countries, including the US, used the data (Sexton 2008). This case testifies to a heightened level of acceptance of this type of whistleblowing by public authorities, although it provoked sharp conflict between Germany and Liechtenstein, and debate within Germany (Spiegel staff 2008). Kieber became an international fugitive with a new identity provided by the German 
government. This controversy indicates only the beginning of a whistleblowing system that lacked a legitimizing framework at the time.

In the second case in Table 1, Rudolf Elmer, who had been chief operating officer of Julius Baer bank's Caribbean offices, actively sought to publicize, without compensation, evidence of tax evasion, contacting public authorities and Wikileaks. In the following years, Elmer was imprisoned for 200 days, but the Zurich high court rejected efforts to prosecute him for breaking Swiss secrecy laws, and he has been applauded as a whistleblower by the Tax Justice Network (Fowler 2017). This indicates a further institutionalization of the taxation whistleblowing system.

The third case is one of the most successful ones. It involves the US Internal Revenue Service's (IRS) use of information acquired from Bradley Birkenfeld, a former employee of the Swiss bank UBS. Birkenfeld served 2.5 years in jail for his own role in the tax evasion scheme. However, in 2012 Birkenfeld received US\$104 million from the IRS as a reward for his information (Hilzenrath 2009). ${ }^{14}$ The many effects of his information included recovery of US\$780 million and the communication of thousands of names. Worry about figuring among the disclosed contributed to more than US $\$ 5.5$ billion being collected through the IRS Offshore Voluntary Disclosure Program (Ventry 2014). Additional impacts included the closure of Swiss banking programs and the winding down of Swiss bank secrecy. In 2016, Birkenfeld's information was used by French authorities against French tax evaders (Binetti 2016). ${ }^{15}$ The scale of the effects in this case indicates a further strengthening of the whistleblowing system.

The remaining seven cases illustrate the increasing prominence since 2013 of two consortia of journalists, the ICIJ and European Investigative Collaborations (EIC). As discussed in more detail below, the ICIJ and EIC have begun to establish a legitimizing framework for the whistleblowing cases they have worked with, by developing and applying standards that pertain to the ethics of the information disclosures, including whether they are in the public interest, how they can be organized to be most effective for this public interest, whether the information is reliable and whether rights to privacy are considered. Consistent with the types of interactions illustrated in the conceptual section above, Table 1 also displays the interactions of specialized bodies, such as Wikileaks or the ICIJ, with public authorities, tax ministries and courts, civil society and other actors. Overall, then, Table 1 displays the emergence and progressive strengthening of a global tax whistleblowing system over the past decade.

Beyond the individual cases, and at the broadest global public level, are the treaties and the G20 principles discussed previously. However, these primarily operate in the background to legitimize the idea of tax whistleblowing. An important organization that advocates for the strengthening of a global whistleblowing system to address tax evasion specifically is TI, established in 1993 with a focus on combating corruption. Tax evasion is closely associated with

${ }^{14}$ Also see <https://www.belfasttelegraph.co.uk/news/world-news/whistleblowing-rewardunited-states-pays-65m-to-former-convict-and-swiss-banker-28791431.html $>$.

${ }^{15}$ See <http://www.whistleblowersblog.org/articles/tax-whistleblowers/>, a rich source of information on tax whistleblowing. 
corruption because corruption involves spending and receiving money that are hidden from the tax authorities inside as well as across national borders. TI has documented the problems associated with tax evasion in different countries around the world, and it has organized various meetings and made proposals to rectify legislation (TI 2015). The organization is heavily involved in formulating whistleblower policies for states to implement in the belief that governments are ultimately responsible for defending the rights of their citizens. ${ }^{16}$ However, another private actor, the Tax Justice Network (TJN) maintains that TI is too concerned with corruption in developing countries, which admittedly exists, and less focused on the offshore financial institutions. ${ }^{17}$ Nevertheless, the efforts of TI and the TJN are complementary in strengthening of the norms that legitimize whistleblowing in the area of tax evasion.

One of the most important developments in the whistleblowing system is the prominent and growing role of the ICIJ, and its displacement of WikiLeaks, which is the focus of the next section.

\section{The International Consortium of Investigative Journalists}

A decade ago, WikiLeaks might have appeared to be the key private organization facilitating tax-related whistleblowing at the global level. However, it now appears that it has played a relatively peripheral role, and the lead has been taken by the ICIJ. Arguably, the legitimizing framework provided by the ICIJ is a key reason for this change, and an indicator of the gradual institutionalization of the whistleblowing system for global tax issues.

WikiLeaks, launched in 2006 by Julian Assange, became especially prominent in 2010 with its release of over 250,000 sensitive and confidential US embassy cables. In that release Assange made the documents available to five news organizations, which in turn promised to protect individuals by redacting identities and exercising discretion about what information should be released (Leigh 2010). However, in subsequent years, WikiLeaks gradually abandoned this cautious approach and was criticized for releasing critical personal information.

As noted above, Elmer, a former employee of the bank Julius Baer, provided data on 2000 accounts to Julian Assange in 2011 (Lynn 2011; Seamark 2011). Although Wikileaks publicized this leak, the organization has not been a major vehicle for tax whistleblowers since. ${ }^{18}$ Following the Panama Papers leak, WikiLeaks even attacked the ICIJ, for instance, with a tweet stating, 'Washington DC based Ford, Soros funded soft-power tax-dodge "ICIJ" has a WikiLeaks problem. ${ }^{19}$ In part, the dispute was fuelled by different visions of how information should be managed and shows how new organizations and

\footnotetext{
16 <https://www.transparency.org/files/content/activity/2009_PrinciplesForWhistleblowing Legislation_EN.pdf $>$.

${ }^{17}$ See, for instance, the TJN's evaluation of corruption: <http://www.taxjustice.net/topics/ inequality-democracy/corruption/ $>$.

${ }^{18}$ The WikiLeaks information on this leak is at <https://wikileaks.org/wiki/Bank_Julius_ Baer $>$. The absence of other major tax information on WikiLeaks can be confirmed by scanning its list of leaks (<https://wikileaks.org/-Leaks-.html>) and by Google searching 'WikiLeak' and 'tax', which primarily returns information on the Julius Baer leak.

${ }_{19}$ <https://twitter.com/wikileaks/status/717454569861611520>.
} 
emergent properties of whistleblowing adapt when carving out their different roles. While the specific motivations of the individuals who initiated the Swiss, Luxembourg, Panama, Offshore and Paradise leaks are unknown, it is likely that the leaks were directed to the ICIJ instead of WikiLeaks because of the greater prudence and credibility of the former, as well as the greater specialization of the ICIJ on tax evasion issues.

ICIJ identifies itself as 'a global network of more than 200 investigative journalists in 70 countries ... focusing on issues that do not stop at national frontiers: cross-border crime, corruption, and the accountability of power' ${ }^{20}$ It was formed in 1997 as a branch of the Center for Public Integrity, which has received funding from the Soros Foundation. In February 2017, it became an independent news organization and, in July 2017, it was granted non-profit status by US tax authorities. It has a well-defined, conventional and transparent governance structure, with a Board of Directors, an Advisory Committee composed of experienced investigative journalists and a Network Committee, 'a working body of ICIJ members who represent the ICIJ members, setting principles and best practices, priorities and activities, liaising with the board and giving advice to the ICIJ Executive on adding or excusing members. ${ }^{21}$ All the names of the members of these committees are posted on the ICIJ website, with descriptions of their experience.

ICIJ mobilizes conventional journalistic and professional mechanisms to foster trust and credibility and contributes to the type of legitimizing framework discussed above. It seeks to position its work within the traditions of journalism, and, as such, it is a member of the Global Investigative Journalism Network (GIJN). ${ }^{22}$ The ICIJ displays certain features typical of a professional knowledge organization, such as professional standards, and in some respects also functions as a kind of think-tank. Yet, at the same time, an integral part of its strategy is close cooperation with international media in order to influence agenda-setting at the domestic and international levels. Therefore it employs a range of tools similar to those employed by social movements.

The activities of the ICIJ rest on various rules of self-regulation, which the organization has defined for itself. The ICIJ refers to the Code of Ethics of the Society of Professional Journalists, and to additional principles defined by the Center for Public Integrity for the Center and for the Consortium. ${ }^{23}$ It also mentions principles on its website in relation to its general work and in relation to concrete projects. For instance, it notes, 'We are an investigative journalism organization and, as such, we report stories that are in the public interest ... parts of the data are of a private nature and of no interest to the public. The ICIJ will not release personal data en masse' (Guevara 2016). The ICIJ is committed to not turning over documents to governments.

The specific rules of the ICIJ also seek to provide whistleblowers with a maximum degree of anonymity. The ICIJ has developed detailed advice and

${ }^{20}<$ https://www.icij.org/about/>.

${ }^{21}<$ https://www.icij.org/about/>.

22 The GIJN has many other links. \#CumExFiles, a project of Correctiv, another GIJN-related organization, based in Germany, has brought together journalists from 12 European countries to reveal, again on the basis of whistleblowing, how several European countries have been exposed to tax fraud. On Correctiv, see $<\mathrm{https} / / /$ correctiv.org/ueber-uns/>.

${ }^{23}<$ https://www.publicintegrity.org/about/our-work/editorial-policies $>$. 
security mechanisms such as its encrypted SecureDrop server and the use of a Tor browser to protect whistleblowers in the early stages where contacts are being made between whistleblowers and the organization. ${ }^{24}$ The security mechanisms show that the ICIJ's self-regulation covers more than the principles guiding the work of the journalists and embraces logistical support for whistleblowing. Furthermore, the ICIJ has expanded its capacity for directly disseminating the information it provides, including its searchable database with more than 520,000 entities from four different leaks and its use of social media.

Joining the ICIJ is voluntary but the ICIJ has established admission criteria and encourages applications. As the ICIJ notes: 'we sometimes work with journalists and media organizations in countries where we haven't done work before. We vet those new partners thoroughly' (Guevara 2016). Joining implies that members must respect the code as an integral part of the organization. These compliance rules echo a pattern found in many professional associations where members must observe codes of self-regulation.

While the impacts of the information disseminated by the ICIJ are ongoing and not fully measurable, it is clear that they are having serious consequences. The ICIJ's activities have had significance for the firms, governments and individuals they have exposed, as well as for public authorities' tax-related policies and investigations. As of 2017, there were at least 150 investigations going on in 79 countries in response to the Panama Papers. ${ }^{25}$ Other examples of impacts include the pressure the Luxembourg Leaks put on Jean-Claude Juncker when he became head of the European Commission and promised to reform tax policy, after 19 years as Luxembourg's prime minister (Boland-Rudder 2014). In the wake of the Panama Papers former Pakistan prime minister Nawaz Sharif was disqualified from the premiership by the Supreme Court of Pakistan, and then he, his daughter and his son-in-law were indicted in 2017 by an anti-corruption court (Hamilton 2017). Australia's Tax Commissioner has written to other countries to propose joint action in response to data on tax issues made public by the ICIJ (Chenoweth 2014). In March 2018, the chair of a British parliamentary subcommittee cited the Paradise Papers in commenting on the committee's launch of an investigation of tax evasion (Bowers 2018). These examples confirm the types of interactions characteristic of whistleblowing systems as set out in the conceptual section above, as well as the effectiveness of whistleblowing in contributing to deterring or punishing wrongdoing.

\section{Specialization in global whistleblowing: EIC and 'Football Leaks'}

This section briefly discusses the case of 'Football Leaks', which was primarily managed by EIC rather than the ICIJ, but otherwise is very similar to the ICIJ cases. The emergence of new and specialized initiatives indicates a differentiation and regional specialization within the emerging global whistleblowing system for tax issues, as well as further confirming the decentralized but effective character that whistleblowing systems have at the global level.

\footnotetext{
$24<$ https://www.icij.org/leak/>.

$25<$ http://www.journalismfestival.com/pressreleases-2017/football-leaks-and-panamapapers-two-tales-of-great-journalism/ $>$.
} 
Starting in December 2016 under a new platform called 'Football Leaks', a significant number of documents, totalling 1.9 terabytes, has been released. This was, in fact, the biggest leak ever in the world of sport. ${ }^{26}$ The documents, including contracts and agreements, show how both a large number of professional football players, various agents and intermediaries as well as football clubs have been involved in different kinds of financial transactions to avoid tax by manipulating or violating existing tax laws. The Football Leaks platform itself was created by a secret group of whistleblowers, whose spokesperson, 'John', has managed to conceal his identity so far (Buschmann and Wulzinger 2016; Gordon 2015).

The organization behind Football Leaks is the EIC, which was formed in 2016 by media organizations in nine European countries specializing in investigative journalism, and led by Der Spiegel from Germany. ${ }^{27}$ EIC covers a variety of issues other than taxation, current projects including one on the International Criminal Court and one on the flow of weapons, in addition to Football Leaks and a project on Malta's role in tax evasion. ${ }^{28}$ Only one member (medium) per country is admitted, thereby guaranteeing the partners' and funders' exclusive commercial rights to the material and to the publication of results. EIC pools resources in joint investigation and dissemination of results and evaluation of documents provided by whistleblowers and other sources. Therefore, investigations not only accumulate material from various informants, including anonymous sources, but also encourage whistleblowing activity. As argued by EIC, this form of cooperation should be viewed in a broader institutional context: 'Due to their structure and methodology, collaborative networks are one of the few mechanisms able to keep up with the globalized power structures (i.e. governments, corporations), thus becoming the only way forward for investigative journalism. ${ }^{29}$ The governing principles of EIC focus more on the goal of constructing the network than on protecting whistleblowers or journalistic integrity, and the governance structure is not well defined, and thus EIC's self-regulatory capacity is less developed than the ICIJ's. For Football Leaks, EIC worked with 12 European media organizations and over 60 journalists reporting in 13 languages. It had to grapple with legal injunctions in some of its members' countries, as well as logistical issues such as the timing of publications. Overall, its capacity for collaboration was enhanced by its management of the Football Leaks information. ${ }^{30}$

Overall the case of EIC and Football Leaks follows a similar pattern to the ICIJ and its work, albeit in a less rigorous and robust way. It shows how whistleblowing systems emerge globally and become institutionalized in the area of tax evasion. The regional specialization of EIC is an indicator of the overall maturation of the global whistleblowing system for taxation and shows that this new global regulatory instrument is not only associated with US actors, even if historically the US has made the most use of whistleblowing in its public policies.

$26<$ https://footballleaks2015.wordpress.com/>.

$27<$ http://www.spiegel.de/international/der-spiegel-and-eight-other-media-foundinvestigative-network-a-1084054.html $>$.

${ }^{28}<$ https:/ / eic.network/\#projects $>$.

$29<$ https://eic.network/>.

$30<$ http://www.journalismfestival.com/pressreleases-2017/football-leaks-and-panamapapers-two-tales-of-great-journalism/ $>$. 
The effectiveness of whistleblowing in regulating global tax evasion

The global tax-related cases of whistleblowing examined in this section confirm the conceptual discussion of emergent whistleblowing systems in the previous section. The amount and significance of disclosed information has been increasing over time. It has been facilitated by the roles played by an increasingly varied mix of actors and institutions, as the many individual cases display, including, for instance, the general norm-setting role of TI, the assessment and publicizing roles of the ICIJ and EIC, and enforcement through both the reputational and legal consequences of the whistleblowing. While these actors and institutions are varied, they are not random but rather display the roles and relationships set out in the model of emergent whistleblowing system. Multiple motivations and incentives are evident, including the desire of the ICIJ to find a sustainable business model for cross-border investigative journalism, the desire of public authorities to use new methods to find and punish tax evaders and the desire of TI to extend its campaign on corruption into the area of taxation. Public moral outrage at tax evasion is also evident. The growing acceptance and use of information disclosed by the different cases of whistleblowing, and the norms governing the processing of information by the ICIJ have contributed to the emergence of a 'legitimizing framework' that distinguishes public-interested whistleblowing from harmful information disclosures. The effectiveness of these arrangements is evident in the very large sums of money that have been recovered, as well as the damage to the reputations of those who have engaged in illicit activities relating to tax evasion.

It is unlikely that all the tax-related cases of whistleblowing discussed above would have occurred or had the impact they did in the absence of the emerging system highlighted in this paper. In earlier cases, especially Kieber and Birkenfield, the encouragement or acceptance of the information about global tax evasion by German and US authorities, and their willingness to provide a monetary reward, involved a shift in the acceptability and legitimacy of this type of whistleblowing. In the cases managed by the ICIJ or EIC the credibility, organization and impact of the disclosed information was vastly amplified by the coordinated efforts of the journalists involved. Had all the raw data simply been recklessly posted on WikiLeaks with no care taken to evaluate the veracity, or the public interest in disclosing private information, then it is less likely that the general public or public officials or single journalists would have taken them as seriously. The efforts of public authorities to identify and punish the leaker would have also potentially been stronger than their efforts to punish the tax evaders.

\section{Conclusions}

This paper has argued that whistleblowing, rather than being a series of individual acts, is an emergent and increasingly institutionalized regulatory instrument that is disseminating and strengthening globally. The global spread of whistleblowing as a regulatory instrument is evident in the growing consensus in the G20 and other international bodies about best practices on whistleblowing, as well as the introduction of whistleblowing protection in an increasing 
number and variety of countries. The paper has developed the concept of an 'emerging whistleblowing system', identified its major features and analysed how these features reflect current trends in global governance and regulation. These systemic properties include a mix of public and private actors and institutions, which interact vertically and horizontally. Vertically, private organizations, including firms, which are closer to the whistleblower, may have voluntary procedures governing whistleblowing, formal law and coercive sanctions being provided by public institutions. Horizontally, the different functions, stages and sequences involved in establishing and sustaining the organizations involved in whistleblowing come together in a disaggregated manner. As in global governance and regulation more generally, the emergent and complex character of these forms of organization can often obscure their capacities and effectiveness when interacting.

As with similar types of global governance and regulation, especially those with significant presence of private rules, whistleblowing can be controversial. The concept of a 'legitimizing framework' helps assess the public-interestedness of a whistleblowing system.

The second part of the paper applied the concept of an emerging whistleblowing system and a legitimizing framework to the case of global tax evasion. It focused on the role played by the ICIJ and how the latter has displaced WikiLeaks in the area of taxation. The large volume of information that the ICIJ has processed and published, interacting with public, business and other non-governmental actors, continues to have important effects around the world. The ICIJ itself has grown in its significance and capacity, and in Europe a similar institution has emerged with EIC and its processing of Football Leaks.

Overall, global tax evasion is a complex issue to govern. However, certain advances have been made. A whistleblowing system has emerged as an increasingly institutionalized instrument to combat global tax evasion. While this system involves private actors, especially the ICIJ, it also has mechanisms to evaluate the public interest in whistleblowing, and to mobilize effective sanctions, as national public authorities respond to the information made public. More work is needed by researchers and practitioners to understand the organizations involved and to define a more explicit and specific legitimizing framework. Public authorities in the G20 and OECD and at the national level should continue to encourage whistleblowing as an instrument for regulating global problems such as tax evasion, while continuing to refine agreed global norms associated with it, such as when it is legitimate to offer monetary rewards to whistleblowers. Public authorities should also actively pursue leads provided through the work of the ICIJ and EIC. By making the regulatory potential of whistleblowing systems more visible, this paper contributes to their further development and strengthening, to address not just tax evasion, but also other global problems characterized by governance deficits.

\section{Acknowledgements}

Previous versions of this paper have been presented at the 2016 International Political Science Association Congress, Poznan, Poland; the 2017 International Studies Association annual meeting in Baltimore; and the 
2017 International Conference on Public Policy, Lee Kuan Yew School of Public Policy, Singapore. Comments from participants in those sessions, and from the editor and referees of this journal are gratefully acknowledged, as is research assistance by Sutina Chou.

\section{Funding}

Social Sciences and Humanities Research Council of Canada Insight Grant \#435-2016-0527.

\section{Notes on contributor}

Tony Porter is Professor in the Department of Political Science, McMaster University. His most recent books, all with Routledge, are Transnational Financial Associations and the Governance of Global Finance: Assembling Power and Wealth (2013), coauthored with Heather McKeen-Edwards, his edited Financial Regulation after the Global Financial Crisis (2014), and Time, Globalization and Human Experience: Interdisciplinary Explorations (2017), coedited with Paul Huebener, Susie O’Brien, Liam Stockdale and Yanqui Rachel Zhou, (2017). Karsten Ronit is Associate Professor at the University of Copenhagen, Denmark. His most recent books are Global Consumer Organizations (Routledge 2015) and his edited Business and Climate Policy: The Potentials and Pitfalls of Private Voluntary Programs (United Nations University Press, 2012). Email: tporter@mcmaster.ca

Karsten Ronit is Associate Professor at the University of Copenhagen, Denmark. His most recent books are Global Consumer Organizations (Routledge 2015) and his edited Business and Climate Policy: The Potentials and Pitfalls of Private Voluntary Programs (United Nations University Press, 2012).

Email: kr@ifs.ku.dk

\section{References}

Abbott, Kenneth W. and Duncan Snidal (2009) 'The governance triangle: regulatory standards institutions and the shadow of the state' in Walter Mattli and Ngaire Woods (eds) Politics of Global Regulation (Princeton: Princeton University Press), $44-88$.

Andrade, Julio A. (2015) 'Reconceptualizing whistleblowing in a complex world', Journal of Business Ethics, 128:2, 321-335.

Ayres, Ian and John Braithwaite (1992) Responsive regulation: transcending the deregulation debate, (New York: Oxford University Press).

Best, Jacqueline and Alexandra Gheciu (2011) The return of the public in global governance, (Cambridge: Cambridge University Press).

Binetti, Ashley (2016) 'Sounding the alarm: US whistleblower's involvement in French UBS investigation', Whistleblower Protection Blog, 25 February, <http://www. whistleblowersblog.org/2016/02/articles/news/sounding-the-alarm-u-s-whistleblowers-involvement-in-french-ubs-investigation/>, accessed 23 June 2016.

Boland-Rudder, Hamish (2014) 'Pressure on Juncker at G20 Summit over 'Lux Leak' revelations', 12 November, <https://www.icij.org/investigations/luxembourgleaks/pressure-juncker-g20-summit-over-lux-leaks-revelations $/ \geq$, accessed 22 December 2017. 
Bowers, Simon (2018) 'British inquiry promises 'no stone left unturned' as it tackles tax avoidance and evasion,' https://www.icij.org/investigations/paradise-papers/ british-inquiry-promises-no-stone-left-unturned-tackles-tax-avoidance-evasion/, accessed 19 March 2018.

Broderick, Christina Orsini (2007) 'Qui tam provisions and the public interest: an empirical analysis', Columbia Law Review, 107:4, 949-955.

Buschmann, Rafael and Michael Wulzinger (2016) 'Whistleblower exposes top players' contracts', Spiegel Online, 6 February, <http://www.spiegel.de/international/ world/football-leaks-offers-new-contract-revelations-a-1075896.html $\geq$, accessed 22 December 2017.

Chenoweth, Neil (2014) “We will take action:' Australian tax chief calls for global probe into leak revelations', ICIJ, 6 November $6,<$ https://www.icij.org/investigations/ luxembourg-leaks/we-will-take-action-australian-tax-chief-calls-global-probe-leak/>, accessed 22 December 2017.

Cho, Yoon Jik and Hyun Jin Song (2015) 'Determinants of whistleblowing within government agencies', Public Personnel Management, 44:1, 103-132.

Etienne, Julien (2015) 'Different ways of blowing the whistle: explaining variations in decentralized enforcement in the UK and France', Regulation E Governance, 9:4, 309-24.

Fowler, Naomi (2017) 'Whistleblower Rudolf Elmer may soon release account data from Julius Baer bank', Tax Justice Network webpage, August 3, <https://www.taxjustice.net/ 2017/08/03/whistleblower-rudolf-elmer-may-soon-release-account-data-julius-baerbank/>, accessed June 11, 2018.

Franck, Thomas (1990) The power of legitimacy among nations, (Oxford: Oxford University Press).

Gordon, James Patrick (2015) 'Football has its own version of WikiLeaks now', Paste, 16 December, <https://www.pastemagazine.com/articles/2015/12/football-has-itsown-version-of-wikileaks-now.html $>$, accessed 22 December 2017.

Greenberg, Andy (2016) 'How reporters pulled off the Panama Papers, the biggest leak in whistleblower history', Wired, 4 April, <http://www.wired.com/2016/04/reporterspulled-off-panama-papers-biggest-leak-whistleblower-history/ $>$, accessed 27 April 2016.

Guevara, Marina Walker (2016) 'Frequently asked questions about the ICIJ and the Panama Papers', 6 April, <https://panamapapers.icij.org/blog/20160406-FAQs.html>, accessed 22 December 2017.

Hamilton, Martha (2017) 'Former Pakistan PM Nawaz Sharif, family members indicted', ICIJ, 20 October, <https://panamapapers.icij.org/20171020-pakistan-pm-sharif-indicted. html $>$, accessed 22 December 2017.

Harding, Luke (2016) 'Panama Papers: Denmark buys leaked data to use in tax evasion inquiries', Guardian 7 September, <https://www.theguardian.com/news/2016/ sep/07/panama-papers-denmark-becomes-first-country-to-buy-leaked-data > , 2016, accessed 12 June 2018.

Hilzenrath, David S. (2009) 'For American who blew whistle, only reward may be a jail sentence,' Washington Post, 20 August, < http://www.washingtonpost.com/wpdyn/content/article/2009/08/19/AR2009081901386.html>, accessed 22 December 2017.

Leigh, David (2010) 'US embassy cables leak sparks global diplomatic crisis', The Guardian, 28 November, <https://www.theguardian.com/world/2010/nov/28/usembassy-cable-leak-diplomacy-crisis $>$, accessed 22 December 2017.

Levi-Faur, David (2005) 'The global diffusion of regulatory capitalism', The Annals of the American Academy of Political and Social Science, 598:1, 12-32.

Lynn, Matthew (2011) 'It's hardly a trade secret: offshore banks must adapt or die in the Wikileaks era', Sydney Morning Herald, 26 January, 6.

Mattli, Walter and Ngaire Woods, eds. (2009) The politics of global regulation (Princeton: Princeton University Press).

Near, Janet P. and Marcia P. Miceli (1985) 'Organizational dissidence: The case of whistle-blowing', Journal of Business Ethics, 4:1, 1-16.

Near, Janet P. and Marcia P. Miceli (2016) 'After the wrongdoing: what managers should know about whistleblowing', Business Horizons, 59:1, 105-14. 
Porter, Tony and Karsten Ronit (2006) 'Self-regulation as policy process: the multiple and criss-crossing stages of private rule making', Policy Sciences, 39:1, 41-72.

Porter, Tony and Karsten Ronit, eds. (2010) The challenges of global business authority: democratic renewal, stalemate, or decay? (Albany: SUNY Press).

Porter, Tony and Karsten Ronit (2015) 'Implementation in international business selfregulation: the importance of sequences and their linkages', Journal of Law and Society, 42:3, 413-33.

Seabrooke, Leonard and Duncan Wigan (2017) 'The governance of global wealth chains', Review of International Political Economy, 24:1, 1-29.

Seamark, Michael (2011) 'Now Wikileaks plans to reveal Swiss bank account details of 'tax evader' celebrities and politicians', MailOnline, 22 December, http://www. dailymail.co.uk/news/article-1347950/WikiLeaks-reveal-Swiss-bank-accountdetails-tax-evader-celebrities-politicians.html, accessed 22 December 2017.

Sexton, Elisabeth (2008) 'Door shut on tax havens; Lowy files laid bare, Swiss bank turmoil', Sydney Morning Herald, 18 July.

Simmons, Beth (2001) 'International politics of harmonization: the case of capital market regulation', International Organization, 55:3, 589-620.

Simmons, Beth A. and Zachary Elkin (2004) 'The globalization of liberalization: policy diffusion in the international political economy', American Political Science Review, 98:1, 171-189.

Spiegel staff (2008) Liechenstein's shadowy informant: Tax whistleblower sold data to US. Spiegel. February 25. http://www.spiegel.de/international/business/ liechtenstein-s-shadowy-informant-tax-whistleblower-sold-data-to-the-us-a-537640. html, accessed June 11, 2018.

Stigler, George J. (1971) 'The theory of economic regulation', Bell Journal of Economics and Management Science, 2:1, 3-21

Ting, Michael M (2008) 'Whistleblowing', American Political Science Review, 102:2, 249-267.

Transparency International (2015) 'Tax systems: a channel for corruption - or a way to fight it?' Working Paper 15, Berlin, available at https://www.transparency.org/ whatwedo/publication/working_paper_03_2015_tax_systems_a_channel_for_corruption_ or_a_way_to_figh, accessed 22 December 2017.

Vandekerckhove, Wim (2006) Whistleblowing and organizational social responsibility: a global assessment. Aldershot, Hampshire, England; Burlington, VT: Ashgate.

Ventry, Dennis J. (2014) 'Not just Whistling Dixie: the case for tax whistleblowers in the States,' Villanova Law Review, 59:3 425-501.

Walker, Andrew (2015) 'Why shouldn't we protect internal whistleblowers? Exploring justifications for the Asadi decision', New York University Law Review, 90:5, 1761-1785.

White, Micah (2016) 'The Panama Papers: leaktivism's coming of age', The Guardian, 5 April, <http://www.theguardian.com/news/commentisfree/2016/apr/05/ panama-papers-leak-activism-leaktivism>, accessed 27 April 2016. 